\title{
Editor's Note: Special Issue on Network and Parallel Computing for New Architectures and Applications
}

๑) Springer Science+Business Media, LLC, part of Springer Nature 2018

International Journal of Parallel Programming gratefully acknowledges the editorial work of the scholars listed below on the special issue entitled "Network and Parallel Computing for New Architectures and Applications."

\section{Xuanhua Shi}

Huazhong University of Science and Technology

China

\section{Hong An}

University of Science and Technology of China

China

\section{Mahmut Kandemir}

Pennsylvania State University

USA

\section{Hai Jin}

Huazhong University of Science and Technology

China

\section{Chao Wang}

University of Science and Technology of China

China

Publisher's Note Springer Nature remains neutral with regard to jurisdictional claims in published maps and institutional affiliations. 